\title{
Analisis Kinerja Keuangan Untuk Menilai Tingkat Kesehatan Koperasi Karyawan Kodim Palembang
}

\author{
Kasini Novita Sari ${ }^{1}$, Muhamad Aryo Arifin ${ }^{2}$, Emilda ${ }^{3}$ \\ ${ }^{1}$ Fakultas Ekonomi dan Bisnis Universitas PGRI Palembang, novitasari118@gmail.com \\ ${ }^{2}$ Fakultas Ekonomi dan Bisnis Universitas PGRI Palembang, aryo arifin@yahoo.com \\ ${ }^{3}$ Fakultas Ekonomi dan Bisnis Universitas PGRI Palembang, Emilzahra@yahoo.co.id
}

\begin{abstract}
This study aims to determine the level of health of the Palembang KODIM Business Cooperative 2017-2019 based on the Regulation of the Minister of Cooperatives and Small and Medium Enterprises of the Republic of Indonesia Number 06 / Per / Dep.6 / IV / 2016 concerning aspects of capital, efficiency and liquidity. This research is a quantitative descriptive research. The subject of this research is the Palembang KODIM Makmur Business cooperative. The data analysis technique in this research is descriptive quantitative. In this study the data were collected through documentation and literature study methods.
\end{abstract}

Keywords: Capital aspects, efficiency aspects, liquidity aspects.

\begin{abstract}
ABSTRAK
Penelitian ini bertujuan untuk mengetahui tingkat kesehatan koperasi Usaha Makmur KODIM Palembang tahun 2017-2019 berdasarkan pada Peraturan Menteri Koperasi dan Usaha Kecil dan Menengah Republik Indonesia Nomor 06/Per/Dep.6/IV/2016 yang menyangkut atas aspek permodalan, efisiensi, dan likuiditas. Penelitian ini merupakan jenis penelitian deskriptif kuantitatif. Subjek penelitian ini adalah koperasi Usaha Makmur KODIM Palembang. Teknik analisis data dalam penelitian ini adalah deskriptif kuantitatif. Dalam penelitian ini data yang dikumpulkan melalui metode dokumentasi dan studi pustaka.
\end{abstract}

Kata Kunci : Aspek permodalan, aspek efisiensi, aspek likuiditas.

\section{A. PENDAHULUAN}

Koperasi merupakan bagian penting dalam sistem perekonomian bangsa.Koperasi merupakan salah satu badan usaha yang memberikan kontribusi positif dan sangat signifikan dalam peningkatan perekonomian Indonesia. UndangUndang RI Nomor 25 Tahun 1992 tentang perkoperasian menjelaskan bahwa Koperasi adalah badan usaha yang beranggotakan orang-seorang atau badan hukum koperasi dengan melandaskan kegiatannya berdasarkan prinsip koperasi sekaligus sebagai gerakan ekonomi rakyat yang berdasarkan atas asas kekeluargaan.

Berdasarkan Undang-Undang Dasar Republik Indonesia Nomor 17 Tahun 2012, ada empat jenis koperasi yaitu: (1) koperasi produksi, (2) koperasi konsumsi, (3) koperasi jasa, dan (4) koperasi simpan pinjam. Usaha koperasi dikelola berdasarkan asas dan prinsip serta tujuan-tujuan yang ingin dicapai, utamanya untuk meningkatkan kesejahteraan para anggotannya.Anggota dalam menjalankan kegiatan usahanya atau memenuhi kebutuhan sehari-hari membutuhkan dana atau modal yang digunakan untuk kegiatan produktif maupun konsumtif. Kebutuhan dana atau modal tersebut dapat diperoleh dari modal sendiri atau modal pinjaman. Melihat hal diatas maka sebagian besar masyarakat lebih memilih sumber dana dari 
koperasi simpan pinjam karena selain dilihat dari bunga yang relative masih ringan dan kemudahan prosedur, juga akan mendapatkan bagian sisa hasil usaha yang diperoleh koperasi setiap tahun.

Penilaian kinerja keuangan koperasi dapat dilakukan dengan menganalisis rasio-rasio keuangan koperasi, diantara nya rasio permodalan, rasio likuiditas, rasio efisiensi dengan berpedoman pada Peraturan Menteri Negara Koperasi dan Usaha Kecil dan Menengah Republik Indonesia Nomor 14/Per/M.KUKM/XII/2009 tentang pedoman penilaian kesehatan koperasi simpan pinjam dan unit simpan pinjam koperasi terdapat tiga aspek yang menjadi pedoman dalam penilaian kesehatan koperasi, yaitu aspek permodalan, aspek efisiensi, aspek likuiditas.

Pasal 33 ayat 1 Undang-Undang Dasar 1945 menyebutkan bahwa perekonomian Indonesia disusun sebagai usaha bersama atas dasar kekeluargaa. Dengan adanya pasal tersebut, maka bentuk usaha yang tepat adalah koperasi.Karena koperasi merupakan lembaga perekonomian rakyat yang dapat digunakan untuk mewujudkan kesejahteraan sosial, khususnya untuk anggota koperasi itu sendiri.Tujuan utama koperasi sebagai wadah perekonomian rakyat adalah untuk mewujudkan kesejahteraan angota pada khususnya dan pada umumnya, serta ikut membangun tatanan perekonomian nasional. Dengan adanya tujuan tersebut, maka koperasi perlu diselenggarakan atau dikelola dengan sebaik mungkin. Dalam tatanan perkonomian Indonesia, koperasi diharapkan dapat berkembang sebagai badan usaha yang kuat dan mempunyai pengaruh yang baik dalam pertumbuhan perekonomian di Indonesia. Koperasi Karyawan KODIM Palembang bernama lengkap koperasi "USAHA MAKMUR KODIM PALEMBANG"dimana koperasi Usaha Makmur tersebut memiliki kegiatan utama yaitu usaha simpan pinjam. Untuk mengetahui bagaimana kinerja keuangan koperasi "USAHA MAKMUR KODIM PALEMBANG" dalam menjalankan usahanya sudah baik atau masih ada yang perlu dibenahi, penulis ingin melakukan penelitian dengan menganalisis keuangan Koperasi "USAHA MAKMUR KODIM PALEMBANG" berdasarkan SK Menkop, Pengusaha Kecil dan Menengah No. 194/KEP/M/IX/1998 Tentang Petunjuk Pelaksanaan Penilaian Kesehatan Koperasi Simpan Pinjam dan Unit Simpan Pinjam.

\section{B. KAJIAN TEORI}

Bab 1 pasal 1 Undang-Undang Republik Indonesia (UU RI) No. 25 Tahun 1992 tentang perkoperasian, yang dimaksud dengan koperasi adalah badan usaha yang beranggotaan orang-orang atau badan hukum koperasi dengan melandaskan kegiatannya berdasarkan prinsip koperasi sekaligus sebagai gerakan ekonomi rakyat yang berdasarkan atas asas kekeluargaan.

Wuwungan (2015) menyatakan Koperasi memerlukan pencatatan akuntansi dalam menunjang usahanya.IAI mengeluarkan Standar Akuntansi Keuangan Entitas Tanpa Akuntabilitas Publik (SAK-ETAP) untuk diterapkan oleh entitas-entitas tertentu dalam penyajian laporan keuangannya.Koperasi adalah salah satu entitas yang termasuk dalam kategori untuk menerapkan SAK-ETAP.

Sedangkan menurut UU No.25/1992 yang dimaksud dengan koperasi di Indonesia adalah suatu badan usaha yang lebih memiliki dasar asas kekeluargaan.Koperasi adalah badan usaha yang beranggotakan orang-orang atau badan hukum koperasi dengan melandaskan kegiatannya pada prinsip koperasi sekaligus sebagai gerakan ekonomi rakyat yang berdasarkan asas kekeluargaan. Ikatan Akuntansi Indonesia wilayah Sumatera Selatan (2012:175) dalam bukunya 
berjudul "Pengantar Akuntansi Berbasis SAK ETAP" mengertikan koperasi merupakan: "suatu usaha yang terdiri dari kumpulan orang-orang bukan modal, artinya aktivitas koperasi harus benar-benar mengutamakan kesejahteraan anggota."

Dari pengertian koperasi beberapa sumber tersebut dapat penulis simpulkan, koperasi merupakan badan usaha bergerak dalam bidang perekonomian untuk memperbaiki nasib penghidupan yang beranggotakan orang-seorang atau badan hukum koperasi dengan pemisahan kekayaan para anggota koperasi sebagai modal untuk menjalankan usaha yang berdasarkan kekeluargaan.Koperasi salah satu bentuk badan hukum entitas bisnis yang cukup banyak digunakan di Indonesia, yang didirikan dengan hukum UU No. 25 tahun 1992 Tentang Perkoperasian. Dasar pendirian sebuah perusahaan dengan bentuk koperasi adalah pada akte notaris yang di daftarkan di Kepanitiaan Pengadilan Negara dan Kementerian Hukum dan HAM.

\section{Tujuan Koperasi}

Tujuan Koperasi di Indonesia dinyatakan dalam pasal 3 UU RI No. 25 tahun 1992 yaitu, koperasi bertujuan memajukan kesejahteraan anggota pada khususnya dalam masyarakat pada umumnya, serta membangun tatanan perekonomian nasional dalam rangka mewujudkan masyarakat yang maju, adil dan makmur berdasarkan Pancasila dan Undang-Undang Dasar 1945. Dari tujuan tersebut dijelaskan bahwa koperasi di Indonesia adalah meningkatkan taraf hidup anggotanya dan masyarakat pada umumnya melalui wadah perkoperasian.

\section{Fungsi dan Peran Koperasi}

Pada Pasal 4 UU RI No. 25 tahun 1992, di tanyakan bahwa fungsi dan peran Koperasi sebagai berikut:

a. Membangun dan mengembangkan potensi dan kemampuan ekonomi anggota pada khususnya untuk meningkatkan kesejahteraan ekonomi dan sosialnya.

b. Berperan serta aktif dalam upaya mempertinggi kualitas kehidupan manusia dan masyarakat.

c. Memperkokoh perekonomian rakyat sebagai dasar kekuatan dan ketahanan perekonomian nasional ndengan koperasi sebagai sokogurunya.

d. Berusaha untuk mewujudkan dan mengembangkan perekonomian nasional yang merupakan usaha bersama berdasarkan atas asas kekeluargaan dan demokrasi ekonomi.

\section{Koperasi Simpan Pinjam \\ Pengertian Koperasi Simpan Pinjam}

Rudianto (2010:51) Koperasi simpan pinjam adalah koperasi yang bergerak dalam bidang pemupukan simpanan dana dari anggotannya, untuk kemudian dipinjamkan kembali kepada para anggota yang memerlukan bantuan dana. Kegiatan utama koperasi simpan pinjam adalah menyediakan jasa penyimpanan dan pinjamna dana kepada anggota koperasi. Walaupun pemupukan modal dilakukan koperasi dan para anggotanya, sering kali jumlah uang yang ingin dipinjam oleh anggota lebih besar dari modal yang dimiliki koperasi.Karena itu, tidak jarang koperasi harus meminjam uang dari kreditor di luar koperasi, seperti bank atau koperasi kredit. 


\section{Pengawasan Koperasi Simpan Pinjam}

Koperasi Simpan Pinjam dan Unit Simpan Pinjam Koperasi oleh pemerintah dalam hal ini Menteri di tingkat pusat dan pejabat yang diberi wewenang menjalankan tugas pembantuan ditingkat daerah dengan tujuan agar Pengelolaan Koperasi Simpan Pinjam dan Unit Simpan Pinjam Koperasi dilakukan secara baik dan terkendali sehingga membutuhkan Berdasarkan Peraturan Menteri Negara Koperasi dan UKM Nomor 21/Per/M.KUKM/XI/2008 tentang Pedoman Pengawasan Kopeasi Simpan Pinjam dan Unit Simpan Pinjam Koperasi, dijelaskan pegertian bahwa: "pengawasan adalah kegiatan pembinanan, pemantauan, pemeriksaan dan penilaian kesehatan kepercayaan dari pihak terkait". Sedangkan pemeriksaan adalah proses untuk meyakini kebenaran atas penyajian laporan keuangan pertanggung jawaban pengurus koperasi baik dari aspek organisasi, aspek pengelolaan dan aspek keuangan koperasi”. Menurut Peraturan Menteri Negara Koperasi dan UKM Nomor 21/Per/M.KUKM/XI/2008 disebutkan bahwa, bertujuan pengawasan Koperasi Simpan Pinjam dan Unit Simpan Pinjam Koperasi adalah sebagai berikut:

1) Mengendalikan KSP dan USP Koperasi agar dalam menjalankan kegiatan usahanya sesuai dengan ketentuan hukum yang berlaku;

2) Meningkatkan citra dan kredibilitas KSP dan USP Koperasi sebagai lembaga keuangan yang mampu mengelola dana dari anggota, calon anggota, koperasi lain dana tau anggotanya berdasarkan prinsip koperasi;

3) Menjaga dan melindungi asset KSP dan USP Koperasi dari tindakan Penyelewengan oleh pihak-pihak yang tidak bertanggung jawab;

4) Meningkatkan transparansi dan akuntabilitas pengelolaan KSP dan USP Koperasi terhadap pihak-pihak yang berkepentingan;

5) Mendorong pengelolaan KSP dan USP Koperasi mencapai tujuannya secara efektif dan efisien yaitu meningkatkan pemberdayaan ekonomi anggota.

\section{Analisis Penilaian Tingkat Kesehatan Koperasi}

Penilaian tingkat kesehatan koperasi menurut peraturan Deputi Bidang Pengawasan Kementrian Koperasi dan Usaha Kecil dan Menengah Republik Indonesia Nomor: 06/Per/Dep.6/IV/2016 adalah penilaian untuk mengukur tingkat kesehatan KSP dan USP koperasi. Penilaian tingakat kesehatan KSP dan USP koperasi diklarifikasikan dalam 4 kategori, yaitu sehat, cukup sehat, dalam pengawasan dan dalam pengawasan khusus.Peraturan Deputi Bidang Pengawasan Kementerian Koperasi dan Usaha Kecil dan Menengah Republik Indonesia Nomor:06/Per/Dep.6/IV/2016 tentang Pedoman Penilaian kesehatan Koperasi Simpan Pinjam (KSP) dan Unit Simpan Pinjam (USP) Koperasi. Berikut tata cara Penilain Tingkat Kesehatan Koperasi Simpan Pinjam dan Unit Simpan Pinjam:

\section{Permodalan}

Koperasi simpan pinjam memperoleh modal dari, oleh, dan untuk anggota. Koperasi simpan pinjam tidak diperkenankan menerima dana darai luar anggota baik dalam betuk pinjaman maupun hibah terutama untuk modal kerja. Untuk rasio antara modal sendiri terhadap total aset ditetapkan sebagai berikut:

\section{a. Rasio modal sendiri terhadap total aset}

Rasio ini membandingkan antara modal sendiri dengan total aset koperasi.

Rumus :

$$
\frac{\text { Modal Sendiri }}{\text { Total Aset }} \text { X 100\% }
$$


1) Untuk rasio modal sendiri dengan total aset lebih kecil atau sama dengan $0 \%$ diberikan nilai 0 ;

2) Untuk setiap kenaikan rasio 4\% mulai dari $0 \%$ nilai ditambah 5 dengan maksimum niali 100;

3) Untuk rasio lebih besar dari $60 \%$ sampai rasio $100 \%$ setiap rasio kennaikan $4 \%$ nilai dikurang 5;

4) Nilai dikalikan bobot sebesar $6 \%$ diperoleh skor permodalan;

Tabel Standar perhitungan skor Rasio Modal Sendiri terhadap Total Aset

\begin{tabular}{|c|c|c|c|}
\hline Rasio Modal (\%) & Nilai & Bobot (\%) & Skor \\
\hline 0 & 0 & 6 & 0 \\
\hline $1-20$ & 25 & 6 & 1,50 \\
\hline $21-40$ & 50 & 6 & 3,00 \\
\hline $41-60$ & 100 & 6 & 6,00 \\
\hline $61-80$ & 50 & 6 & 3,00 \\
\hline $81-100$ & 25 & 6 & 1,50 \\
\hline
\end{tabular}

(sumber: permen KUKM No.06/Per/Dep.6/IV/2016)

b. Rasio modal sendiri terhadap pinjaman yang berisiko.

Yaitu standar perhitungan skor rasio modal sendiri terhadap pinjaman yang diberikan dikurangi dengan simpanan pokok ditambah simpanan wajib.

Rumus:

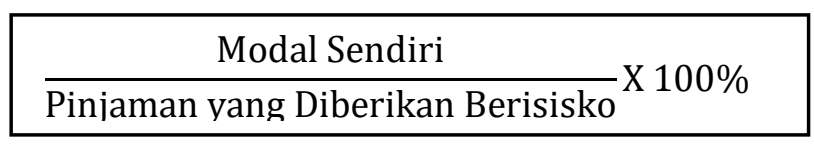

1) Untuk rasio modal sendiri terhadap pinjaman diberikan yang berisiko lebih kecil atau sama dengan $0 \%$ diberi 0 .

2) Untuk setiap kenaikan rasio $1 \%$ mulai dari $0 \%$ nilai ditambah 1 dengan nilai maksimum 100.

3) Nilai dikalikan bobot sebesar 6\%, maka diperoleh skor permodalan.

Tabel Standar perhitungan Skor Rasio Modal Sendiri terhadap Pinjaman Diberikan yang Beresiko

\begin{tabular}{|c|c|c|c|}
\hline Rasio Modal (\%) & Nilai & Bobot (\%) & Skor \\
\hline 0 & 0 & & 0 \\
\hline $1-10$ & 10 & 6 & 0,6 \\
\hline $11-20$ & 20 & 6 & 1,2 \\
\hline $21-30$ & 30 & 6 & 1,8 \\
\hline $31-40$ & 40 & 6 & 2,4 \\
\hline $41-50$ & 50 & 6 & 3,0 \\
\hline $51-60$ & 60 & 6 & 3,6 \\
\hline $61-70$ & 70 & 6 & 4,2 \\
\hline $71-80$ & 80 & 6 & 4,8 \\
\hline $81-90$ & 90 & 6 & 5,4 \\
\hline $91-100$ & 100 & 6 & 6,0 \\
\hline
\end{tabular}

(sumber;permenKUKMNo.06/Per/Dep.6/IV/2016) 


\section{c. Rasio kecukupan modal sendiri}

Standar perhitungan skor rasio kecukupan modal sendiri

$$
=\frac{\text { Modal Sendiri Tertimbang }}{\text { ATMR }} \times 100 \%
$$

1) Rasio kecukupan modal sendiri adalah perbandingan Modal Sendiri Tertimbang dengan Aktiva Tertimbang Menurut Risiko (ATMR) dikalikan dengan 100\%.

2) Modal tertimbang adalah jumlah dari hasil kali setiap komponen modal KSP/USP koperasi pada neraca dengan bobot pengakuan risiko.

3) ATMR adalah jumlah dari hasil setiap komponen aktiva KSP dan USP Koperasi yang terdapat pada neraca dengan bobot pengakuan risiko.

4) Menghitung nilai ATMR dilakukan dengan cara menjumlahkan hasil perkalian nilai nominal aktiva yang ada dalam neraca dengan bobot risiko masing-masing komponen aktiva.

5) Rasio kecukupan modal sendiri dapat dihitung/diperoleh dengan cara membandingkan nilai modal tertimbang dengan nilai ATMR dikalikan dengan $100 \%$.

Tabel Standar Perhitungan Rasio Kecukupan Modal Sendiri

\begin{tabular}{|c|c|c|c|}
\hline Rasio Modal (\%) & Nilai & Bobot (\%) & Skor \\
\hline$<4$ & 0 & 3 & 0.00 \\
\hline $4 \leq x<6$ & 50 & 3 & 1.50 \\
\hline $6 \leq x \leq$ & 75 & 3 & 2.25 \\
\hline$>8$ & 100 & 3 & 3.00 \\
\hline (sumber; permen KUKM No.06/Per/Dep.6/IV/2016)
\end{tabular}

\section{Efisiensi}

Penilaian aspek ini bertujuan untuk menggambarkan sampai berapa saat KSP atau USP koperasi mampu memberikan layanan yang efisien kepada anggotannya dari penggunaan aset yang dimilikinya. Adapun penilain aspek efisien sebagai berikut:

a) Rasio Beban Operasional Pelayanan terhadap Partisipasi Bruto.

Rasio ini dihitung dengan rumus sebagai berikut:

$$
\frac{\text { Beban Operasi anggota }}{\text { Partisipasi Bruto }} \text { X 100\% }
$$

Cara perhitungan rasio beban operasi anggota atas partisipasi bruto ditetapkan sebagai berikut:

a. Untuk rasio sama dengan atau lebih besar dari $100 \%$ diberi nilai 0 dan untuk rasio antara 95\% hingga lebih kecil dari $100 \%$ diberi nilai 50 , selanjutnya dari penurunan rasio sebesar 5\% nilai ditambahkan dengan 25 sampai dengan maksimum nilai 100; dan

b. Nilai dikalikan dengan bobot $4 \%$ diperoleh skor penilaian. 


Tabel Standar perhitungan Beban Operasi Anggota
Terhadap Partisipasi Bruto
\begin{tabular}{|c|c|c|c|}
\hline $\begin{array}{c}\text { Rasio Beban Operasi Anggota } \\
\text { terhadap partisipasi Bruto (\%) }\end{array}$ & Nilai & Bobot & Skor \\
\hline$\geq 100$ & 0 & 4 & 1 \\
\hline $95 \leq X<100$ & 50 & 4 & 2 \\
\hline $90 \leq X<95$ & 75 & 4 & 3 \\
\hline$<90$ & 100 & 4 & 4 \\
\hline
\end{tabular}

(sumber; permen KUKM No.06/Per/Dep.6/IV/2016)

a) Rasio beban Usaha terhadap SHU Kotor.

Rasio ini dihitung dengan rumus sebagai berikut:

$$
=\frac{\text { Beban Usaha }}{\text { SHU kotor }} X 100 \%
$$

Rasio beban usaha terhadap SHU Kotor ditetapkan sebagai berikut:

a. Untuk rasio lebih dari $80 \%$ diberi nilai 25 dan untuk setiap penurunan rasio $20 \%$ nilai ditambah dengan 25 sampai maksimum 100, dan

b. Nilai dikalikan dengan bobot sebesar $4 \%$ diperoleh skor nilai.

Tabel Standar perhitungan Rasio Efisiensi Pelayanan

\begin{tabular}{|c|c|c|c|}
\hline $\begin{array}{c}\text { Rasio Beban Usaha } \\
\text { terhadap SHU Kotor (\%) }\end{array}$ & Nilai & $\begin{array}{c}\text { Bobot } \\
(\%)\end{array}$ & Skor \\
\hline$\geq 80$ & 25 & 4 & 1 \\
\hline $60 \leq X<80$ & 50 & 4 & 2 \\
\hline $40 \leq X<60$ & 75 & 4 & 3 \\
\hline$<40$ & 100 & 4 & 4 \\
\hline
\end{tabular}

(sumber; permen KUKM No.06/Per/Dep.6/IV/2016)

\section{b) Rasio Efisiensi Pelayanan.}

Rasio ini dihitung dengan rumus sebagai berikut:

Rumus:

$$
=\frac{\text { Biaya Kariawan }}{\text { Volume Pinjaman }} \times 100 \%
$$

Perhitungan rasio efisiensi pelayaran, ditetapkan sebagai berikut:

a. Untuk rasio lebih dari $15 \%$ diberi nilai 0 dan rasio antara $10 \%$ hingga $15 \%$ diberi nilai 50 , selanjutnya setiap penurunan rasio $1 \%$ nilai di tambah 5 sampai dengan maksimum nilai 100 ;

b. Nilai dikalikan dengan bobot $2 \%$ diperoleh skor penilain

Tabel Standar perhitungan Rasio Efesiensi Pelayanan

\begin{tabular}{|c|c|c|c|}
\hline Rasio Efisiensi Staf (\%) & Nilai & Bobot (\%) & Skor \\
\hline$<5$ & 100 & 2 & 2 \\
\hline $5<\mathrm{X}<10$ & 75 & 2 & 1,5 \\
\hline $10 \leq X \leq 15$ & 50 & 2 & 2 \\
\hline$>15$ & 0 & 2 & 0 \\
\hline
\end{tabular}

(sumber; permen KUKM No.06/Per/Dep.6/IV/2016) 


\section{Likuiditas}

Dalam aspek ini yang ingin diketahui adalah kemampuan Koperasi Simpan Pinjam dan Unit Simpan Pinjam Koperasi untuk memenuhi kewajiban jangka pendeknya.Adapun penilaian aspek likuiditas didasarkan pada 2 (dua) rasio, yaitu.

1) Rasio Kas dan Bank terhadap kewajiban lancar.

Rasio ini dihitung dengan rumus sebagai berikut:

$$
=\frac{\text { Kas dan Bank }}{\text { Kewajiaban Lancar }} \times 100 \%
$$

Pengukuran rasio kas dan bank terhadap kewajiban lancar ditetapkan sebagai berikut:

a. Untuk rasio kas lebih besar dari $10 \%$ hingga $15 \%$ diberi nilai 100 , untuk rasio lebih besar dari $15 \%$ sampai dengan $20 \%$ diberi nilai 50 , suntuk rasio lebih kecil sama dengan $10 \%$ diberi nilai 25 sedangkan untuk rasio lebih dari $20 \%$ diberi nilai 25;

b. Nilai dikalikan dengan bobot $10 \%$ diperoleh skor nilai.

Tabel Standar perhitungan rasio kas terhadap kewajiban lancar

\begin{tabular}{|c|c|c|c|}
\hline Rasio Kas (\%) & Nilai & Bobot (\%) & Skor \\
\hline$\leq 10$ & 25 & 10 & 2,5 \\
\hline $10<X \leq 15$ & 100 & 10 & 10 \\
\hline $15<X \leq 20$ & 50 & 10 & 5 \\
\hline$>20$ & 25 & 10 & 2,5 \\
\hline
\end{tabular}

\section{2) Rasio Pinjaman yang Diberikan terhadap Dana yang Diterima}

Rumus yang digunakan untuk menghitung Rasio Pinjaman yang Diterima terhadap Dana yang Diterima, yaitu:

$$
=\frac{\text { pinjaman yang diterima }}{\text { dana yang diterima }} \times 100 \%
$$
berikut:

Pengukuran rasio pinjaman terhadap dana yang diterima ditetapkan sebagai

a) Untuk rasio pinjaman lebih kecil dari $60 \%$ deberikan nilai 25 , untuk setiap kenaikan rasio $10 \%$ nilai ditambah dengan 25 sampai dengan maksimum 100 .

b) Nilai dikalikan dengan bobot $5 \%$ diperoleh sekor penilaian.

\section{Tabel Standar Perhitungan Rasio Pinjamanyang Diberikan Terhadap Dana yang Diterima}

\begin{tabular}{|c|c|c|c|}
\hline Rasio Pinjaman (\%) & Nilai & Bobot (\%) & Skor \\
\hline$<60$ & 25 & 5 & 1,25 \\
\hline $60 \leq \mathrm{X}<70$ & 50 & 5 & 2,50 \\
\hline $70 \leq \mathrm{X}<80$ & 75 & 5 & 3,75 \\
\hline $80 \leq \mathrm{X}<90$ & 100 & 5 & 5 \\
\hline
\end{tabular}




\section{Kualitas Aktiva produktif}

Aktiva produktif merupakan kekayaan koperasi yang mendatangkan penghasilan bagi koperasi yang bersangkutan. Adapun penilaian aspek kualitas aktiva produktif didasarkan pada 4 (empat) rasio, yaitu:

1. Rasio volume pinjaman pada anggota terhadap total volume pinjaman diberikan Rasio ini dihitung dengan rumus sebagai berikut:

$\frac{\text { Rasio volume pinjaman pada ang gota }}{\text { Total volume pinjaman diberikan }} \times 100$

Tabel Standar perhitungan skor rasio volume pinjaman pada anggota terhadap total pinjaman yang diberikan

\begin{tabular}{|c|c|c|c|}
\hline Rasio (\%) & Nilai & Bobot (\%) & Skor \\
\hline$<25$ & 0 & 10 & 0.00 \\
\hline $26-50$ & 50 & 10 & 5.00 \\
\hline $51-75$ & 75 & 10 & 7.50 \\
\hline$>75$ & 10 & 10 & 10.00 \\
\hline
\end{tabular}

2. Rasio risiko pinjaman bermasalah terhadap pinjaman yang diberikan

Rasio ini dihitung dengan rumus sebagai berikut:

$$
=\frac{\text { pinjaman bermasalah }}{\text { pinjaman yang diberikan }} \times 100 \%
$$

Untuk memperoleh rasio risiko pinjaman bermasalah terhadap pinjaman yang diberikan, ditetapkan sebagai berikut:

a. Menghitung perkiraan besarnya risiko pinjaman bermasalah (RPM) sebagai berikut:

1) $50 \%$ dari pinjaman yang diberikan yag kurang lancar $(\mathrm{PKL})$

2) $70 \%$ dan pinjaman yang diberikan yang diragukan (PDR)

3) $100 \%$ dari pinjaman diberikan yang macet (PR)

b. Hasil penjumlahan tersebut dibagi dengan pinjaman yang diberikan

$R P M \frac{(50 \% \times P K L)+(75 \% \times P D R)+(100 \% \times P M)}{\text { pinjaman yang diberikan }} \times 100 \%$

Perhitungan penilaian:

$>$ Untuk rasio $45 \%$ atau lebih diberi nilai 0 .

$>$ Untuk setiap penurunan rasio $1 \%$ dari $45 \%$ nilai ditambah 2, dengan maksimum nilai 100; dan

> Nilai dikalikan degan bobot $5 \%$ dperoleh skor penilaian.

Tabel Stadar perhitungan RPM

\begin{tabular}{|c|c|c|c|}
\hline Rasio (\%) & Nilai & Bobot $(\%)$ & Skor \\
\hline$>45$ & 0 & 5 & 0 \\
\hline $40<x<45$ & 10 & 5 & 0,5 \\
\hline $30<x \leq 40$ & 20 & 5 & 1,0 \\
\hline $20<x \leq 30$ & 40 & 5 & 2,0 \\
\hline $10<x \leq 20$ & 60 & 5 & 3,0 \\
\hline $0<x \leq 10$ & 80 & 5 & 4,0 \\
\hline 0 & 100 & 5 & 5,0 \\
\hline
\end{tabular}

(sumber; permen KUKM No.06/Per/Dep.6/IV/2016) 
3. Rasio cadangan risiko terhadap rasio pinjaman bermasalah Rasio ini dihitung dengan rumus sebagai berikut:

Rasio cadangan risiko terhadap rasio pinjaman bermasalah

$=\frac{\text { cadangan risiko }}{\text { piniaman bermasalah }} \times 100 \%$

Untuk memperoleh rasio cadangan terhadap risiko pinjaman bermasalah, ditetapkan sebagai berikut:

a. Untuk rasio $0 \%$, berarti tidak mempunyai cadangan penghapusan diberi nilai 0

b. Untuk setiap kenaikan $1 \%$ mulai dari $0 \%$, nilai ditambah 1-100, dan

c. Nilai dkalikan bobot sebesar $5 \%$ diperoleh nilai penilaian.

Tabel Standar cadangan risiko terhadap rasio pinjaman bermasalah

\begin{tabular}{|c|c|c|c|}
\hline Rasio (\%) & Nilai & Bobot & Skor \\
\hline 0 & 0 & 2 & 0 \\
\hline $1-10$ & 10 & 2 & 0,5 \\
\hline $11-20$ & 20 & 2 & 1,0 \\
\hline $21-30$ & 30 & 2 & 1,5 \\
\hline $31-40$ & 40 & 2 & 2,0 \\
\hline $41-50$ & 50 & 2 & 2,5 \\
\hline $51-60$ & 60 & 2 & 3,0 \\
\hline $61-70$ & 70 & 2 & 3,5 \\
\hline $71-80$ & 80 & 2 & 4,0 \\
\hline $81-90$ & 90 & 2 & 4,5 \\
\hline $91-100$ & 100 & 2 & 5,0 \\
\hline
\end{tabular}

(sumber; permen KUKM No.06/Per/Dep.6/IV/2016)

4. Rasio pinjaman yang berisiko terhadap pinjaman yang diberikan

Rasio ini dihitung dengan rumus sebagai berikut:

Rasio pinjaman yang berisiko terhadap pinujaman yang diberikan $=\frac{\text { pinjaman yang berisiko }}{\text { pinjaman yang diberikan }} \times 100 \%$

Tabel Standar perhitungan rasio pinjaman berisiko

\begin{tabular}{|c|c|c|c|}
\hline Rasio (\%) & Nilai & Bobot (\%) & Skor \\
\hline$>30$ & 25 & 5 & 1,25 \\
\hline $26-30$ & 50 & 5 & 2,50 \\
\hline $21-25$ & 75 & 5 & 3,75 \\
\hline$<21$ & 100 & 5 & 5,00 \\
\hline
\end{tabular}

(sumber; permen KUKM No.06/Per/Dep.6/IV/2016)

\section{METODE PENELITIAN}

Metode penelitian adalah ilmiah untuk mendapatkan data dengan tujuan dan kegunaan tertentu. (Sugiono, 2017:2) dalam penelitian ini menggunakan metode Penelitian kuantitatif. Metode penelitian kuantitatif adalah metode penelitian yang melandaskan pada filsafatpositivisme, digunakan untuk meneliti pada populasi dan 
sample tertentu, pengumpulan data menggunakan instrument penelitian, analisis data bersifat kuantitatif.

\section{1) Objek/Lokasi Penelitian}

Objek penelitian adalah Koperasi Usaha Makmur KODIM Palembang. JIn. Di Ponegoro No. 15 palembang.

\section{2) Sumber data}

Sumber data yang digunakan oleh penelitian ini adalah sumber data Primer, sumber data primer adalah data yang dikumpulkan sendiri oleh perorangan atau suatu organisasi secara langsung memberikan data, kepada pengumpul data dari objek yang diteliti dan untuk kepentingan studi yang bersangkutan yang dapat berupa interview, observasi.

\section{3) Teknik Analisis Data}

Metode deskriptif dan kuantitatif adalah metode yang digunakan untuk menggambarkan atau untuk menganalisis suatu hasil penelitian tetapi tidak dgunakan untuk membuat kesimpulan yang lebih luas.Dalam penelitian ini, metode pengumpulan data yang digunakan adalah dokumentasi, dan studi kepustakaan. Teknik analisis data dalam penelitian ini adalah menggunakan analisis deskriptif kuantitatif dengan menganalisis rasio-rasio keuangan yang berpedoman pada Peraturan menteri Koperasi dan Usaha Kecil dan Menengah Republik Indonesia Nomor 06/Dep.6/IV/2016 Tentang Pedoman Penilaian Koperasi Simpan Pinjam dan Unit Simpan Pinjam Koperasi dan faktor-faktor yang mempengaruhi tingkat kesehatan koperasi.

\section{HASIL DAN PEMBAHASAN \\ 1) Aspek Permodalan}

Aspek permodalan dinilai untuk mengetahui informasi mengenai keuangan modal koperasi Usaha Makmur KODIM Palembang dalam mendukung kegiatan operasionalnya. Berikut ini merupakan penjelasan terkait dengan rasio-rasio aspek permodalan berdasarkan hasil penilaian kinerja keuangan koperasi Usaha Makmur KODIM Palembang tahun 2017-2019.

a) Rasio modal sendiri terhadap total aset

Rasio ini digunakan untuk mengetahui tingkat kemampuan modal sendiri pada koperasi Usaha Makmur KODIM Palembang dalam mendukung pendanaan terhadap total aset yang dimilikinya.

Berdasarkan perhitungan modal sendiri terhadap total aset, pada tahun 2017 sebesar 87,67\% menunjukan nilai 25 dengan skor 1,50, maka dapat dikategorikan dalam pengawasan. Pada tahun 2018 terjadi kenaikan sebesar $2,07 \%$ menunjukan nilai 25 dengan skor 1,50, dapat dikategorikan dalam pengawasan dari tahun 2017, Dan pada tahun 2019 terjadi penurunan dari tahun 2018 sebesar 10\% menunjukan nilai 25 dengan skor 1,50, dapat dikategorikan dalam pengawasan. 
b) Rasio modal sendiri terhadap pinjaman diberikan yang berisiko

Rasio ini digunakan untuk mengetahui tingkat kemampuan modal sendiri pada koperasi Usaha Makmur KODIM Palembang dalam mendukung pendanaan terhadap pinjaman diberikan yang berisiko yang dimilikinya.

Berdasarkan perhitungan modal sendiri terhadap pinjaman yang diberikan berisiko, pada tahun 2017 sebesar 4,38\% menunjukan nilai 50 dengan skor 6 , dapat dikategorikan dalam pengawasan khusus. Pada tahun 2018 terjadi kenaikan sebesar 0,33\% menunjukan nilai 50 dengan skor 6, dapat dikategorikan dalam pengawasan khusus. Dan pada tahun 2019 terjadi penaikan kembali seperti tahun 2018 sebesar 0,17\% menunjukan nilai 50 dengan skor 6 , dapat dikategorikan dalam pengawasan khusus.

c) Rasio modal sendiri tertimbang terhadap ATMR

Rasio ini digunakan untuk mengetahui tingkat kemampuan modal sendiri pada koperasi Usaha Makmur KODIM Palembang dalam mendukung pendanaan terhadap ATMR yang dimilikinya.

Berdasarkan perhitungan modal sendiri tertimbang terhadap ATMR, pada tahun 2017 sebesar 87,67\% menunjukan nilai 100 dengan skor 3.00, dapat dikategorikan sehat. Pada tahun 2018 terjadi kenaikan sebesar 2,07\% menunjukan nilai 100 dengan skor 3.00, dapat dikategorikan sehat. dari tahun 2017, Dan pada tahun 2019 terjadi penurunan dari tahun 2018 sebesar 10\% menunjukan nilai 100 dengan skor 3.00, dapat dikategorikan sehat.

Dari Hasil penelitian yang dilakukan ini sesuai dengan hasil penelitian terdahulu yang telah dilakukan oleh Putu Eka (2019) hasil penelitian menunjukan bahwa aspek permodalan tahun 2016-2018 mendapat nilai 25 dengan skor yang dihasilkan 1,50 dan skor maksimal 6. Pada rasio modal sendiri terhadap total asset koperasi dapat dikategorikan Dalam pengawasan, sedangkan rasio modal sendiri terhadap pinjaman yang diberikan berisisko dikategorikan Dalam pengawasan khusus dan pada rasio modal sendiri tertimbang terhadap ATMR dapat dikategorikan Sehat.

\section{2) Efisiensi}

a) Rasio beban usaha terhadap SHU kotor

Penilaian aspek efisiensi bertujuan untuk mengukur tingkat kemampuan koperasi Usaha Makmur KODIM Palembang dalam memberikan pelayanan kepada anggotanya.

Berdasarkan perhitungan rasio beban usaha terhadap SHU kotor pada tahun 2017 sebesar 1,20\% menunjukan nilai 100 dengan skor 4, dapat dikategorikan dalam pengawasan khusus. pada tahun 2018 terjadi penurunan sebesar 0,07\% menunjukan nilai 100 dengan skor 4, dapat dikategorikan cukup sehat. pada tahun 2019 terjadi kenaikan dari tahun 2018, sebesar 0,03\% menunjukan nilai 100 dengan skor 4, dapat dikategorikan dalam pengawasan khusus.

b) Rasio efisiensi pelayanan biaya karyawan terhadap volume pinjaman 
Penilaian aspek efisiensi bertujuan untuk mengukur tingkat kemampuan koperasi Usaha Makmur KODIM Palembang dalam memberikan pelayanan kepada anggotanya.

Berdasarkan perhitungan rasio efisiensi pelayanan pada tahun 2017 sebesar $11,30 \%$ menunjukan nilai 50 dengan skor 1,00 , dapat dikategorikan sehat. pada tahun 2018 terjadi penurunan sebesar 1,44\% menunjukan nilai 75 dengan skor 1,50, dapat dikategorikan sehat. pada tahun 2019 terjadi kenaikan dari tahun 2018, sebesar 1,77\% menunjukan nilai 50 dengan skor 1,00, dapat dikategorikan sehat.

Dari Hasil penelitian yang dilakukan ini sesuai dengan hasil penelitian terdahulu yang telah dilakukan oleh Panduwinata (2019) aspek efisiensi menunjukan nilai 50 dengan skor yang dihasilkan 1,00 dengan maksimal 2, dapat dikategorikan dalam pengawasan khusus. Rasio beban usaha terhadap SHU kotor dapat dikategorikan dalam pengawasan khusus dan pada rasio efisiensi pelayanan biaya karyawan terhadap volume pinjaman dapat dikategorikan sehat.

\section{3) Aspek Likuiditas}

Aspek likuiditas dinilai untuk mengetahui emampuan suatu lembaga menutupi kewajiban jangka panjang dengan menggunakan aset yang paling mudah mengkonversi menjadi uang kas.Berikut ini merupakan hasil penilaian kinerja keuangan koperasi Usaha Makmur KODIM Palembang tahun 2017-2019.

a) Rasio Kas

Penilaian aspek efisiensi bertujuan untuk mengukur tingkat kemampuan koperasi Usaha Makmur KODIM Palembang dalam memberikan pelayanan kepada anggotanya.

Berdasarkan perhitungan rasio kas pada tahun 2017 sebesar 11,54\% menunjukan nilai 100 dengan skor 10, dapat dikategorikan sehat. pada tahun 2018 terjadi penurunan sebesar $10.44 \%$ menunjukan nilai 25 dengan skor 2,5, dapat dikategorikan dalam pengawasan. dari 2017, dan pada tahun 2019 terjadi kenaikan pada tahun 2018 sebesar 13,24\% menunjukan nilai 50 dengan skor 5 , dapat dikategorikan dalam pengawasan khusus.

b) Pinjaman yang diberikan terhadap dana yang diterima

Penilaian aspek efisiensi bertujuan untuk mengukur tingkat kemampuan koperasi Usaha Makmur KODIM Palembang dalam memberikan pelayanan kepada anggotanya.

Berdasarkan perhitungan rasio pinjaman yang diberikan terhadap dana yang diterima pada tahun 2017 sebesar 39,12\% menunjukan nilai 25 dengan skor 1,25, dapat dikategorikan dalam pengawasan. pada tahun 2018 terjadi kenaikan sebesar 9,43\% menunjukan niali 25 dengan skor 1,25, dapat dikategorikan dalam pengawsan. dan pada tahun 2019 terjadi kenaikan dari tahun 2018 sebesar 0,16\% menunjukan nilai 25 dengan skor 1,25, dapat dikategorikan dalam pengawasan.

Dari Hasil penelitian yang dilakukan ini sesuai dengan hasil penelitian terdahulu yang telah dilakukan oleh Panduwinata (2019) menunjukan nilai 25 dengan skor 2,5 dapat dikategorikan dalam pengawasan khusus. 


\section{E. KESIMPULAN DAN SARAN}

1) Kesimpulan

Berdasarkan pengolahan data keuangan yang telah dilakukan, maka dapat diambil kesimpulannya bahwa tingkat kesehatan koperasi Usaha Makmur KODIM Palembang pada tahun 2017-2019 adalah sebagai berikut:

a. Ditinjau dari aspek permodalan, kualitas permodalan pada modal sendiri terhadap total aset koperasi Usaha Makmur KODIM Palembang pada tahun 2017-2019 dapat dikategorikan dalam pengawasan. Pada tahun 2017-2019 modal sendiri terhadap pinjaman diberikan yang berisiko mengalami kenaikan dapat dikategorikan dalam pengawasan khusus. Pada tahun 2017-2019 modal sendiri tertimbang terhadap ATMR mengalami kenaikan, dapat dikategorikan sehat.

b. Ditinjau dari aspek Efisiensi, kualitas efisiensi beban usaha terhadap SHU kotor koperasi Usaha Makmur KODIM Palembang pada tahun 2017 dapat dikategorikan dalam pengawasan khusus. Pada tahun 2018 mengalami kenaikan dapat dikategorikan cukup sehat. Pada tahun 2019 mengalami penurunan. Pada tahun 2017-2019 pada pelayanan biaya karyawan terhadap volume pinjaman dapat dikategorikan sehat.

c. Ditinjau dari aspek Likuiditas, kualitas rasio kas dan bank terhadap kewajiban lancar koperasi Usaha Makmur KODIM Palembang pada tahun 2017 dapat dikategorikan sehat. Pada tahun 2018 mengalami penurunan dapat dikategorikan dalam pengawasan. Pada tahun 2019 mengalami penurunan dapat dikategorikan dalam pengawasan khusus. Pada pinjaman yang diberikan terhadap dana yang diterima pada ahun 2017-2019 dapat dikategorikan dalam pengawasan.

\section{2) Saran}

Berdasarkan kesimpulan yang telah didapat dari hasil analisis tingkat kesehatan koperasi usaha makmur KODIM Palembang periode 2017-2019, maka saran yang simpulkan adalah sebagai berikut:

a. Sebaiknya penghitungan laporan keuangan koperasi Usaha Makmur KODIM Palembang menggunakan peraturan Menteri Koperasi dan Usaha Kecil dan Menengah Republik Indonesia Nomor 06/Per/Dep.6/IV/2016 sehingga dapat melihat kesehatan keuangan koperasi untuk setiap tahunnya.

b. Dilihat dari kualitas permodalan koperasi usaha makmur KODIM Palembang modal sendiri terhadap total aset pada tahun 2017-2019 berada dalam kategori dalam pengawasan, sedangkan modal sendiri terhadap pinjaman diberikan yang berisiko tahun 2017-2019 tejadi kenaikan yaitu dalam kategori dalam pengawasan khusus, dan modal sendiri tertimbang terhadap ATMR pada tahun 2017-2019 terjadi kenaikan lebih baik, maka pengelola koperasi usaha makmur KODIM Palembang dapat meningkatkan kualitas efisiensi yang baik.

c. Dilihat dari kualitas efisiensi koperasi usaha makmur KODIM Palembang beban usaha terhadap SHU kotor pada tahun 2017 berada dalam kategori dalam pengawasan khusus, maka pengelola koperasi usaha makmur KODIM Palembang dapat meningkatkan lagi yang cukup baik menjadi baik. Dan pada tahun 2018 terjadi kenaikan dalam kategori cukup sehat, dan terjadi penurunan kembali pada tahun 2019 dalam kategori dalam pengawasan khusus. Maka pengelola diharapkan dapat mempertahankan kondisi yang cukup baik menjadi 
baik. Sedangkan pada tahun 2017-2019 pada pelayanan biaya karyawan terhadap volume pinjaman terjadi kenaikan yaitu dalam kategori sehat.

d. Dilihat dari kualitas likuiditas rasio kas koperasi usaha makmur KODIM Palembang kas dan bank terhadap kewajiban lancar pada tahun 2017 dalam kategori sehat. Maka pengelola diharapkan dapat mempertahankan kodisi ini untuk setiap tahunnya. Pada tahun 2018-2019 terjadi penurunan yaitu dalam kategori dalam pengawasan. Sedangkan pinjaman yang diberikan terhadap dana yang diterima pada tahun 2017-2019 mengalalami penurunan dengan kategori dalam pengawasan, maka pengelola dapat melakukan perbaikan dalam pengelolaan aspek likuiditas dengan cara menyalurkan dana tersebut ke nasabah dalam bentuk pinjaman, sehingga dapat mengembangkan usahanya dan nanti bisa membesarkan keuntungan yang diperolehnya.

\section{DAFTAR PUSTAKA}

Dewi, Putu Eka, dkk. 2019. Analisis kinerja keungan dan tingkat kesehatan koperasi simpan pinjam tahun 2015-2017. jurnal ilmiah nahasiswa Akuntansi Universitas pendidikan Ganesha, Vol:10 No:2 tahun 2019.

Ikatan Akuntan Indonesia. 2012. Standar Akuntansi Keuangan :Jakarta.

Menteri Negara Koperasi dan Usaha Kecil dan Menengah Republik Indonesia No.14/Per/M.KUKM/XII/2009 tentang Tingkat Kesehatan Koperasi Simpan Pinjam dan Unit Simpan Pinjam.

Panduwinata Fina. (2019). Analisis Kinerja Keuangan pada Koperasi SMK Utama Bakti Palembang.Skripsi. Fakultas Ekonomi, Universitas PGRI Palembang.

Peraturan Deputi Bidang Pengawasan Kementerian Koperasi dan Usaha Kecil dan Menengah No.06/Per/Dep.6/IV/2016 tentang Pedoman Penilaian Koperasi Simpan Pinjam dan Unit Simpan Pinjam.

Peraturan Menteri Koperasi dan Usaha Kecil dan Menengah Republik Indonesia Nomor: 12/Per/M.KUKM/IX/2015 tentang pedoman Umum Akuntansi Koperasi Sektor Rill.

Rudianto. (2010). Akuntansi Koperasi, Erlangga: PT Gelora Aksara Pratama

Sugiyono.2017, Metode Penelitian Bisnis. Bandung: alfabeta.

Undang-Undang Peraturan Menteri Negara Nomor 19 Tahun 2008 Tentang Pedoman Pelaksanaan Kegiatan Usaha Simpan Pinjam Koperasi.

Undang-Undang RI No.17 Tahun 2012 Tentang Perkoperasian.

Undang-Undang No.25 Tahun 1992 Tentang Perkoperasian.

Wuwungan, J.Y.S.2015, Analisis Penerapan Standar Akuntansi Keuangan Entitas Tanpa Akuntabilitas Publik Atas Persediaan Pada Apotik Uno Medika. Jurnal EMBA universitas Sam Ratulangi Manado.http://www.ejournalunsrat.ac.id diakses 8 Februari 2016, Vol.3, No.4.Hal.498-507. 